\title{
CASTALLA (ALICANTE, SPAIN) VERNACULAR ARCHITECTURE: USE, LOSS, OBLIVION AND MEMORY
}

\author{
J. A. Mira ${ }^{1}$, M. Bevià ${ }^{2}$, J. Giner $^{2, *}$ \\ ${ }^{1}$ Open University of Catalonia-ICOMOS Spain - jmirari@uoc.edu \\ ${ }^{2}$ Architect - mariusbg@gmail.com, jaimeginer@arquired.es
}

\section{Commission II - WG II/8}

KEY WORDS: Castalla (Alicante, Spain), Human social structures, Vernacular architecture

\begin{abstract}
:
Vernacular architecture is a reflection of the relationship established by human social structures with their environment and how they take advantage of it for different commercial, economic, productive, pleasure and symbolic-religious purposes. The municipality of Castalla, located in the north of the province of Alicante, is a good example. It is an enclave in which the land use took place from Prehistory thanks to the human communities that mould its landscape. This process was intensified since the eighteenth century with building of pleasure houses, yards, plaster kilns, country houses (in many cases with small chapels) and snow wells, among other constructions. All of them made up a well-preserved landscape until the end of the twentieth century. Its decline took place with the industrialisation of Castalla in the middle of the twentieth century and the emergence of new socio-economic conditions. Consequently, this fact caused the abandonment as well as the oblivion of the material and immaterial characteristics that led to its appearance. This paper will analyse the characteristics of one of these constructions: Casa de la Glorieta (nineteenth century), which is an interesting example of rural buildings in Castalla. In most cases, they are austere country houses aimed basically at the land use. Nevertheless, Casa de la Glorieta (neoclassical style) becomes an ensemble with a double function along with Mas de la Parrotja: to take advantage of the environment and to serve as a pleasure house for the local bourgeoisie.
\end{abstract}

\section{INTRODUCTION}

Castalla is a municipality located in the Foia de Castalla district, a natural depression situated in the southeast of the Iberian Peninsula, specifically in the northwest of the province of Alicante (Spain). The territory has been well studied from a geographical and landscape point of view (Giménez, 2010; Santos, 1987). Therefore, it will only be noted that its height above sea level is $650 \mathrm{~m}$ and that it is surrounded by a mountainous area crossed by a river (riu Verd) which flows into the Mediterranean Sea (Figure 1).

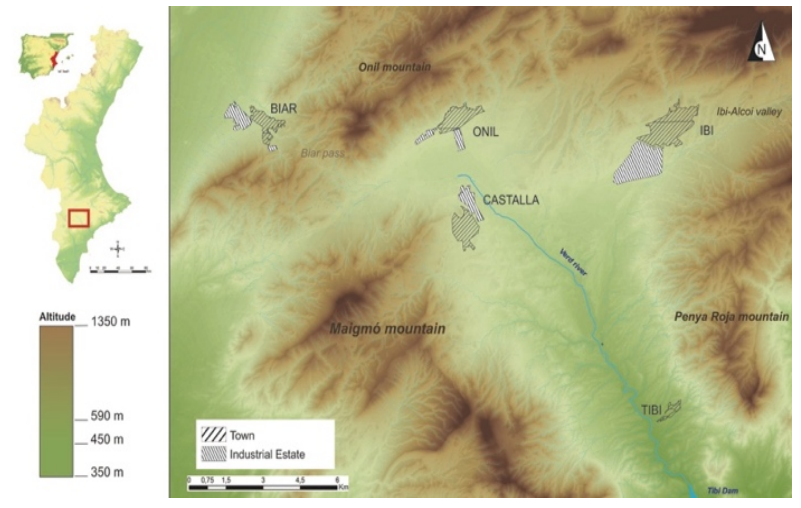

Figure 1. Geographical location of Castalla (Iberian Peninsula, Valencian Community and Foia de Castalla district).

There are many examples of vernacular architecture in Castalla, testimonies of a way of life that contributed to configure and mould the cultural landscape in the past (Figure 2).

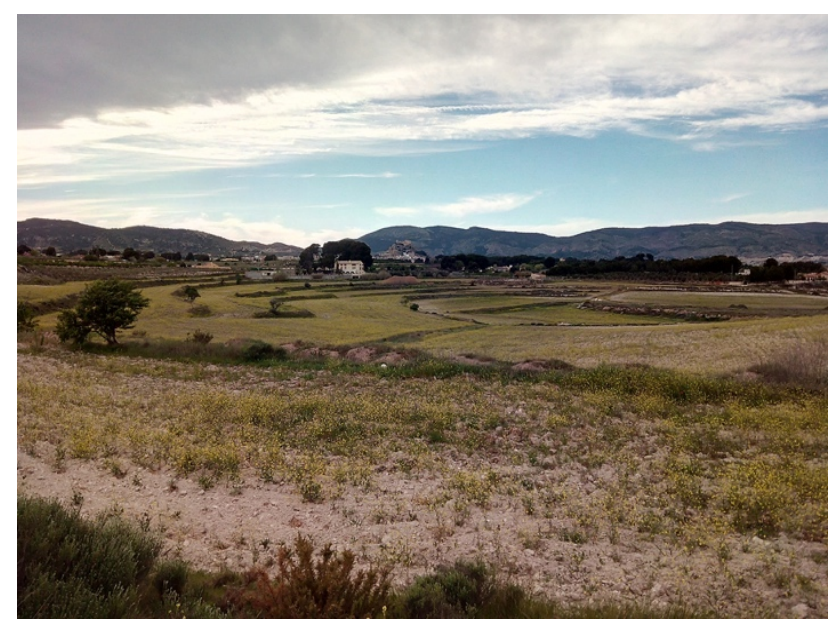

Figure 2. Castalla cultural landscape with plots

Several authors have broached the study of vernacular architecture in the region for scientific and informative purposes from different disciplines, such as anthropology, archaeology, architecture, history and literature. In this sense, there are some reference works on population, architecture and conditions of domestic life in the Valencian Community, such as that of Joan Francesc Mira (1983), or on the countryside of the province of Alicante, such as that of Gabino Ponce and José Fermín Bonmatí (1985). The main works to be highlighted in the Foia de Castalla district are related to plaster kilns of Castalla and Tibi (García, Rizo, 2003), hydraulic constructions and snow wells (Cruz, Segura, 1996; Marquiegui, 2013), as well as those on the general concept of a country house (Bernabeu, 1984), life

* Corresponding author 
in country houses (Valor, 1983) and country houses of Onil (Balaguer, 2009).

In the case of Castalla, although snow wells and plaster kilns have been studied in detail, the absence of concrete studies on pleasure, farms and livestock constructions, such as country houses, can be highlighted. However, Joan Antoni Bellot and Ildefonso Verdú, residents of Castalla, made an extensive photographic report of many of these constructions before their disappearance or further deterioration in 1984. This is an authentic graphic memory of great anthropological, architectural and historical interest that subsequently served as a basis for the development of a didactic exhibition in 2010: Els Masos de Castalla. Un espai de vida $i$ treball (http://www.turismocastalla.com/castalla/gestion/documentos/ Masos_Castalla_130410.pdf).

The graphic compilation made in the 1980s, the disappearance of many constructions due to various factors, as well as the absence of works that analyse the architectural characteristics and the origin, development and disappearance of pleasure houses and country houses in Castalla have motivated an interdisciplinary team made up by cultural heritage specialists and professionals -architects, managers and historians actively involved in their research, preservation, restoration, didactics and dissemination - to design and start the research project Castalla Vernacular Architecture: Use, Loss, Oblivion and Memory, still in an early stage. Its purposes and methodology (heir to the aforementioned initiatives) will be described below.

\section{PURPOSES}

\subsection{General purpose}

The general purpose is to cover the existing gap on research regarding works focused on the studies of pleasure, farm and livestock constructions of the Foia de Castalla district, particularly in the municipality of Castalla.

\subsection{Specific purpose}

This type of purposes encompasses three fundamental premises:

- To establish a typological classification and make an inventory of the studied buildings.

- To know their architectural characteristics, ranging from small and/or medium-sized spaces (usually two floors) to larger structures. In the case of country houses, some of them have their own small chapels (Figure 3). Furthermore, they could house a family nucleus or even several families depending on the size. They could even use more elaborate materials from the immediate environment and include some ornamental decoration too.

- To know their historical evolution until today. Although many pleasure houses and country houses disappeared during the twentieth century, others are still in operation. Some of them -Almarra and Casa de l'Escrivà- have an Andalusian origin (eleventh and twelfth centuries); in other cases -Sarganella-, they emerged during the late Middle Ages (fourteenth and fifteenth centuries) (Mira, 2018), and most of them -Carrascal, Carrascalet, Casa dels Campellos, Cases dels Alfasos, Foia Redona, Font del Llop de Baix, Font del Llop de Dalt, Pas Nou, Pas Vell, Pla de les Caves de Baix or Pla de les Caves de Daltappeared during the eighteenth and nineteenth centuries.

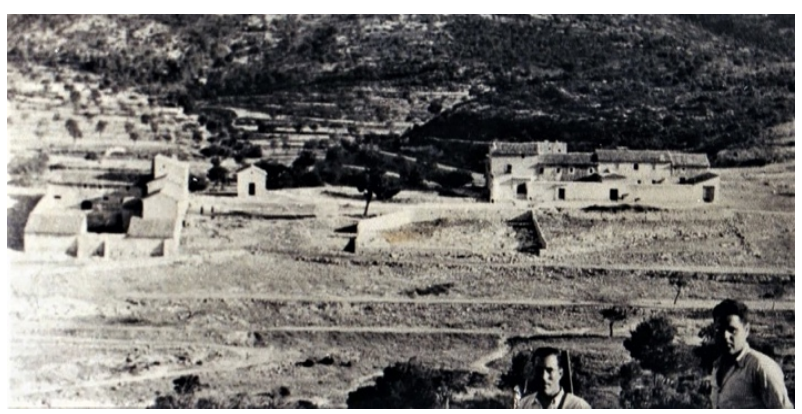

Figure 3. Mas de les Fermoses, a complex country house that has disappeared. Its small chapel was dedicated to Saint Peter Martyr and was blessed by Antonio García on 16 May 1675.

(C) Federico José Cerdà Image Copyright 2020.

\section{METHODOLOGY}

In order to meet the stated purposes, different sources and techniques will be applied to obtain the information in the best conditions and achieve the most reliable analysis. According to the qualitative criteria indicated by Julio Aróstegui Sánchez (2001, p. 387-388), two types of sources take part of this research: material and cultural.

On the one hand, material sources embrace these constructions as well as the marks of people who inhabited or developed their work in them (gardens, plots, communication routes, etc.). On the other hand, there are different types of cultural sources:

- Written sources, which may be non-narrative, and whose search will be carried out in the Municipal Archive of Castalla (Municipal holdings. Section of private works) and in the Directorate General of Land Registry, without excluding the owners' documentation that may help to obtain more data.

- Narrative sources, which are focused on reading different works.

- Oral sources, which come from the information collected through interviews with people linked to the rural world and owners who want to participate.

- Audiovisual sources with old and current photographs of the constructions, which are fundamental to verify the effects of their abandonment and the anthropic action embodied in plundering and destruction (Figure 4). In the case of old photographs, they will be scanned to create a digital file.

The following qualitative research techniques will be applied to both sources: documentary observation of all narrative and nonnarrative cultural sources used; architectural, historical and anthropological analysis to know the characteristics of these constructions, their history and the role they played; and oral research. According to the approaches of different authors (Flick, 2004; Taylor, Bogdan, 2002; Vasilachis, 2006), semistructured interviews will be carried out with the owners, workers and ex-workers of these constructions in order to obtain interesting data about them.

Finally, all the data collected will be included in some files summarising the most relevant information. In addition, building georeferencing will be also highlighted for its subsequent use in geographic information systems that can show different contents: preservation status (disappeared, bad, regular and good), chronology, aim (pleasure, active use or mixed -pleasure and active use-), etc. 


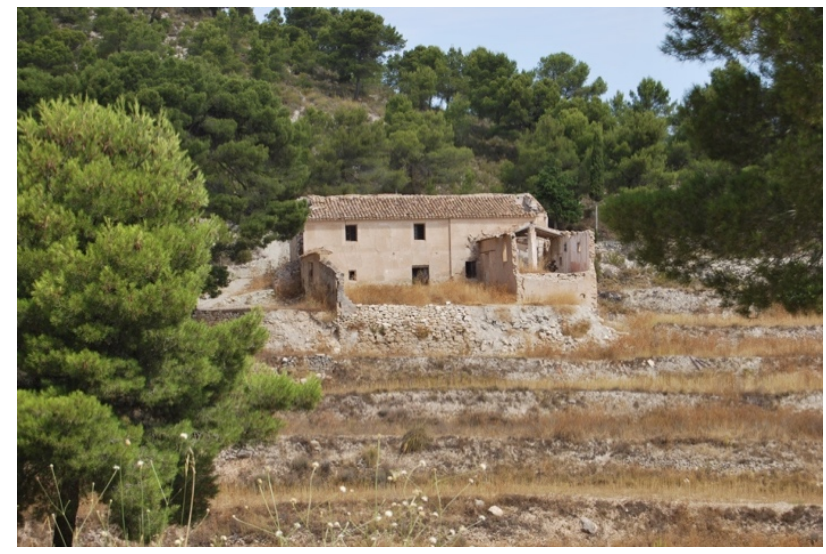

Figure 4. Mas del Litero. The dilapidated state is due to its abandonment and plundering

\section{FIRST STEPS OF A CASE STUDY: CASA DE LA GLORIETA}

The ensemble made up by Casa de la Glorieta and Mas de la Parrotja is located in the plain of Castalla (Figure 5), next to the CV-816 road, which was the historic path to travel to the current municipality of Tibi or different hamlets during the Middle Ages, such as Torreta de Cabanyes or Sarganella. It is also very near the river ( $r i u$ Verd), in a plot that occupies an area of 187,688 square meters and whose UTM coordinates (Huso 30 ETRS 89) are X-705733.74 and Y-4273288.47. In spite of its proximity to the river, this location is not the best for agricultural activities since land use capacity of type $\mathrm{C}$ is characterised by low depth and greyish lands -in a scale in which $\mathrm{A}$ is the best category and $\mathrm{E}$ the worst, following the classification of Enrique Matarredona and Juan Antonio Marco (1991)-. These lands are the most abundant in the district and have a medium capacity intended for the cultivation of olive, almond (still present), cereal, etc. They stand out for their stones, severe erosion risks, imperfect drainage and steep slopes too.

From a typological point of view, this example is a mixed ensemble (the other two types correspond to country houses complex and/or simple- and pleasure houses). This denomination is related to a dual model not abundant in Castalla in which a construction -Casa de la Glorieta- for the pleasure purposes of a local bourgeois family (Torró family) coexists in the same space along with another building aimed at farm and livestock -Mas de la Parrotja-. So far, we have only identified another example with the same scheme: The Casa del Llentisclar, which has a main building for the owners' pleasure, other local bourgeois family (Soler family), along with the country house inhabited by the workers and their families.

On the basis of the architectural analysis, it can be affirmed that both buildings date from the same century: Casa de la Glorieta from the second half of the nineteenth century and Mas de la Parrotja from an indeterminate moment since it is not recorded in other registries of urban and rural wealth in Castalla (fifteenth century -1456 - and sixteenth century 1557-. Municipal Archive of Castalla. Call marks C-582/1 and C-581/2. There are no records from the seventeenth and eighteenth centuries). The current impossibility of accessing the Municipal Archive of Castalla, which is closed for refurbishment, has prevented the consultation of sources related to private works in order to search documentation that may facilitate their dating. However, there is evidence of three notebooks granted by a local neighbour with interesting information for this project. The first notebook is a summary of people who own lands in Castalla and contains land maps classified in areas. Although its chronology is unknown, it could be provisionally dated from the first third of the twentieth century. The other two notebooks, also undated, contain lists of country house owners located in Castalla. These lists include the number of area and plots, the zone occupied and the economic amount paid for those plots as a tax (https://arepaccastalla.wordpress.com/2014/06/20/novadonacio-a-lajuntament-de-castalla/).

On the other hand, the consultations at the Directorate General of Land Registry and the Property Registry of Ibi, which refused to grant access despite explaining the information would be used for scientific purposes, have also been negative. Finally, the family that owns the ensemble was contacted in order to know if they kept documentation that could be studied but not reply has been received. Therefore, it is impossible to specify the chronology of both constructions in more detail.

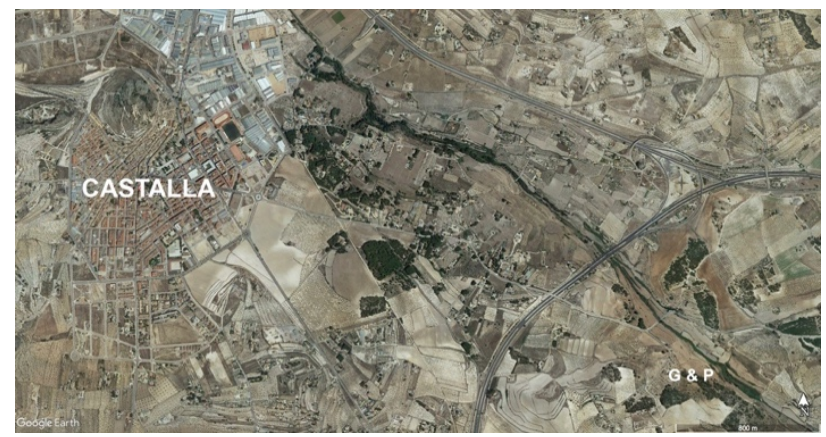

Figure 5. Location of the municipality of Castalla, Casa de la Glorieta $(\mathrm{G})$ and Mas de la Parrotja $(\mathrm{P})$ near the river

The construction of Casa de la Glorieta implied a reorganisation of the pre-existing agricultural space with a pleasure use. Therefore, the house is located on the border between the agricultural irrigated land and a small hill with a twin objective: to avoid the agricultural wasting of Mas de la Parrotja, whose part of land dedicated to this use goes down to the river with a height of $600 \mathrm{~m}$, and to stand out the new building so that it can be observed from different points (Figures 6 and 7).

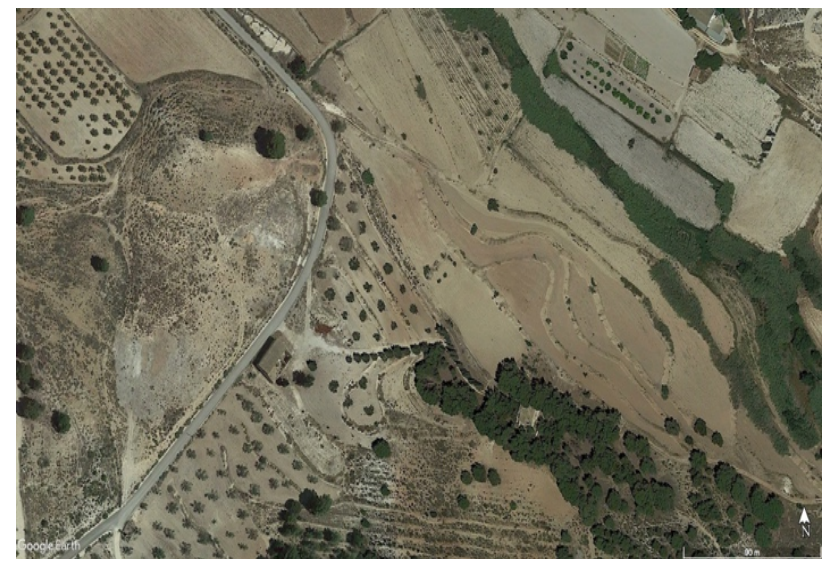

Figure 6. Ortophoto with the location of Casa de la Glorieta and Mas de la Parrotja

From Mas de la Parrotja, which maintained the farm use, and starting off the road -cami de Creuetes- there was a path bordered by cypresses that led to the new house (Figure 8). 


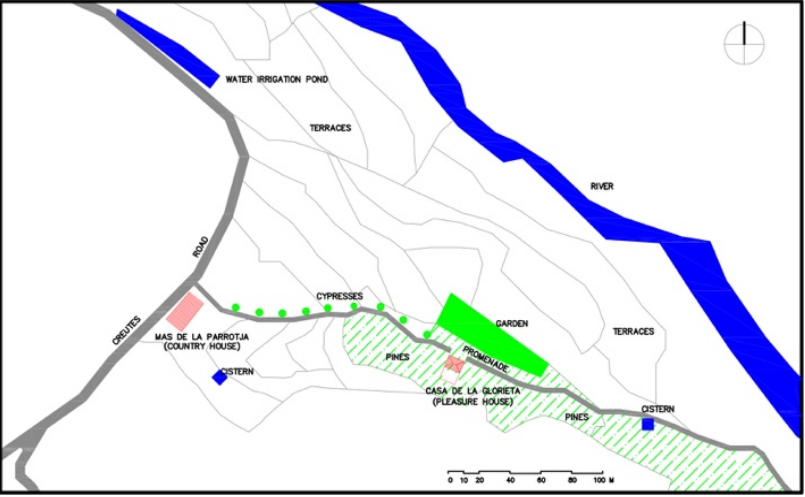

Figure 7. Sketch with the location of Casa de la Glorieta and Mas de la Parrotja.

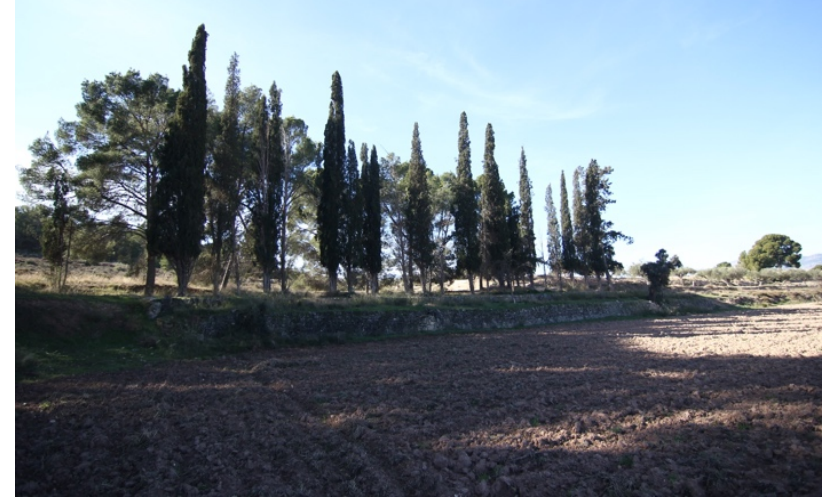

Figure 8. Cypresses path.

Surrounded by a pine plantation, this house had a gorgeous view of the river and the valley (Figure 9). Nowadays, this view is still beautiful as it has not been altered by the construction of the A77 road that broke in two the municipal district of Castalla at the beginning of the twenty-first century. The tree-lined promenade in front of the main façade of the house linked a lower terrace through a wide staircase, where there is a garden completely ruined today (Figure 10). The agricultural production is currently focused on olive and almond trees. These species were already the most cultivated in the municipality of Castalla in the middle of the nineteenth century according to Pascual Madoz (1847). In addition, there is a small forest mass of pines and lands that are not cultivated at present.

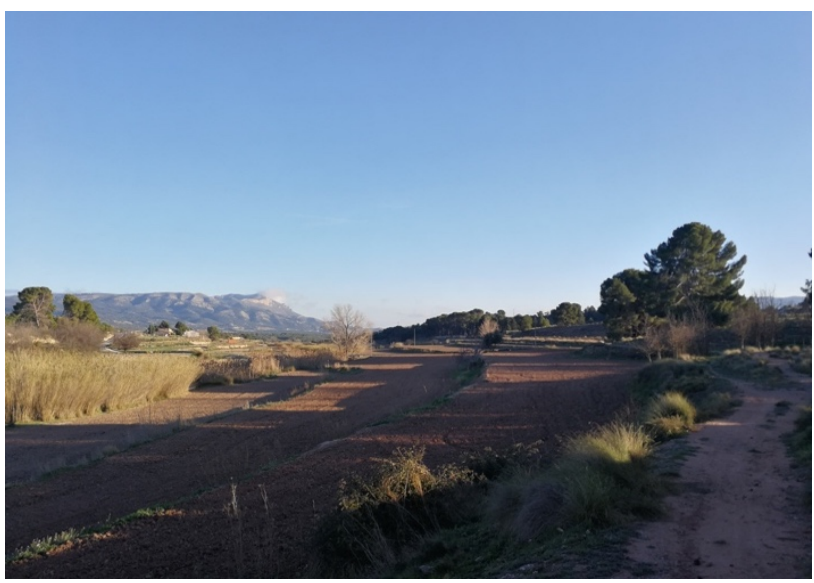

Figure 9. View of the Foia de Castalla district from the area of Casa de la Glorieta.

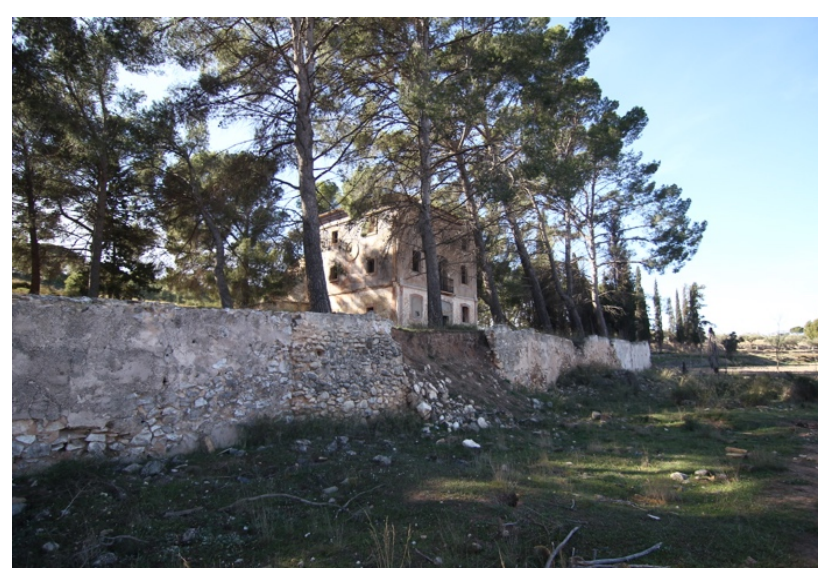

Figure 10. Current view of the garden.

The irrigation water for the land was collected from the river and stored in a pond, and for the drinking water there were two underground cisterns near each house that stored the water coming from the runoff of the slopes of the small hill (Figure 11).

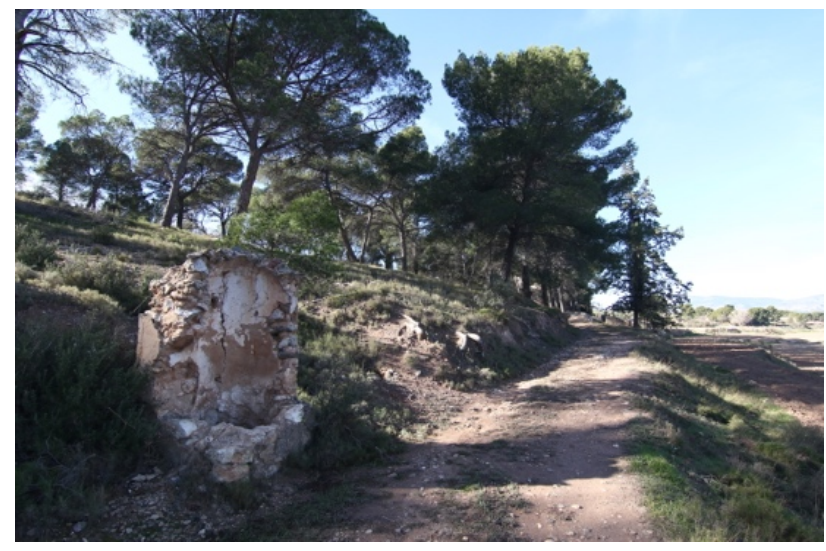

Figure 11. Cistern with a part of the top that protected the missing extraction system. The top, made of quarry stone with pargeting, was built with materials from the surrounding environment.

As already noted, Casa de la Glorieta was built in the second half of the nineteenth century and its stylistic features are related to the models of that time (Figure 12).

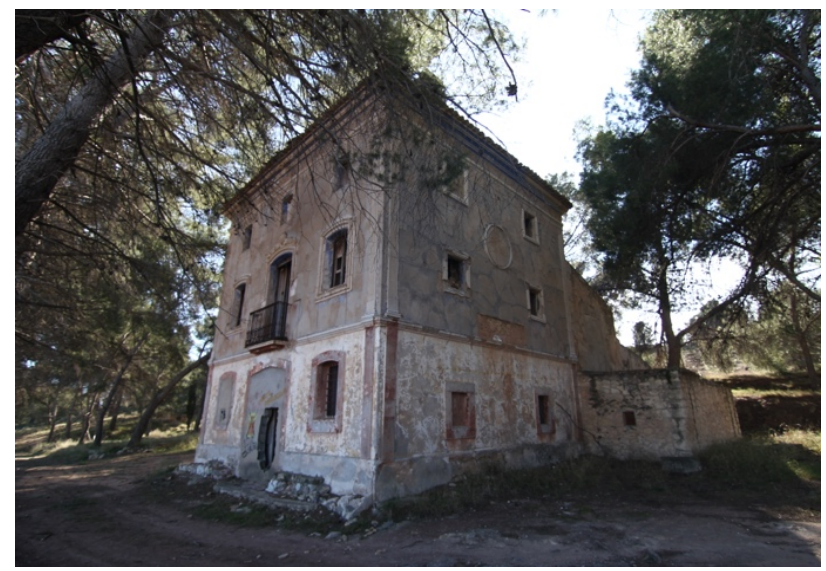

Figure 12. Current view of Casa de la Glorieta. 
It was made up by three quadrangular-based floors, peripheral load-bearing walls and two aligned pillars with inner main beams dividing the space in two bays (Figure 13), where floor slabs of small wooden beams with solid brick flooring blocks rested.

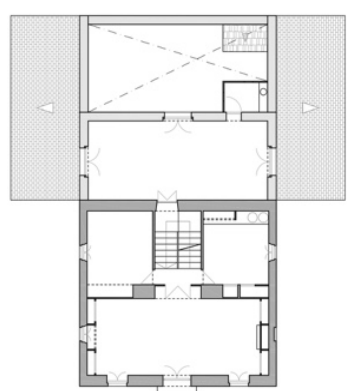

First floor

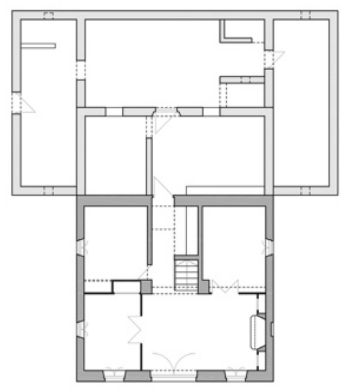

Ground floor

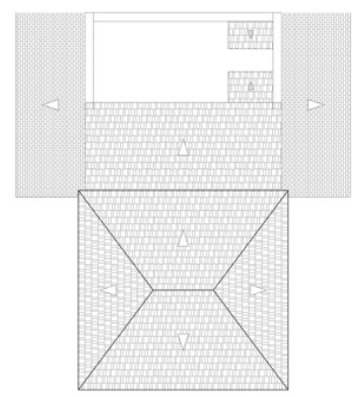

Roof

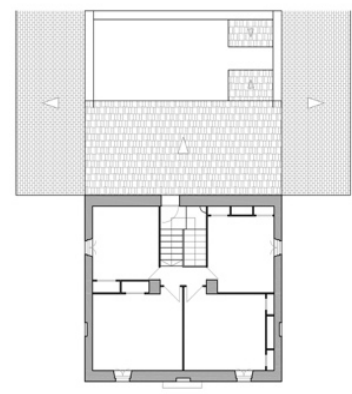

Second floor $\quad E: 1 / 200$
Figure 13. Casa de la Glorieta plan.

The sloping roof consisted of a wood structure with four sides, on which a reed rested (base of the curved roof tiles). The staircase was located on the axis of the building, in the second bay, and was used for the inner distribution of rooms and bedrooms.

On the ground floor, the main door led to a room that occupied almost the entire first bay and was dominated by a large fireplace with architectural decoration and several rooms (Figure 14)

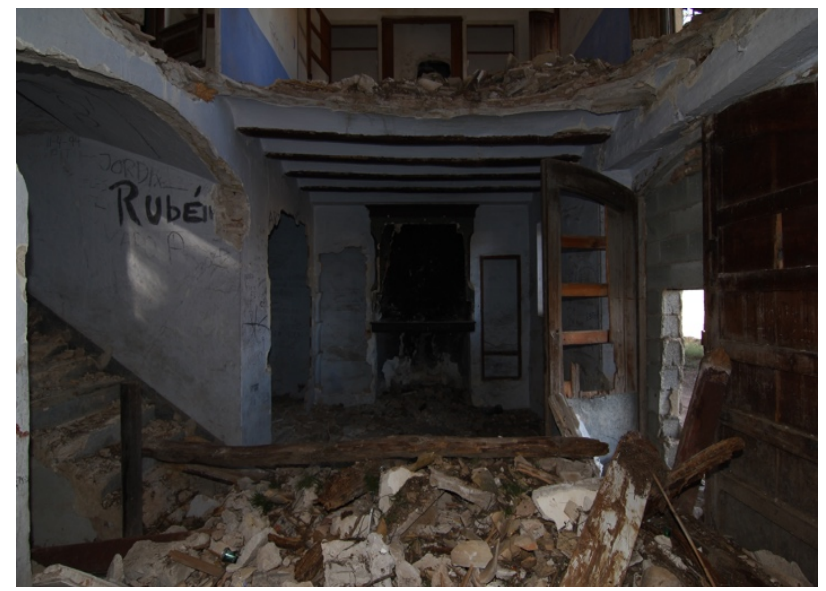

Figure 14. Ground floor with the fireplace.
There was an access under the staircase to the courtyard and back rooms, which were used as storerooms and farmyards (Figures 15 and 16).

This floor was a very representative architectural model of that century, such as Villa Ito of Sant Joan d'Alacant (Varela, 1995, p. 169-176) or the town hall of Biar (Bérchez, Corell, 1981, p. 329).
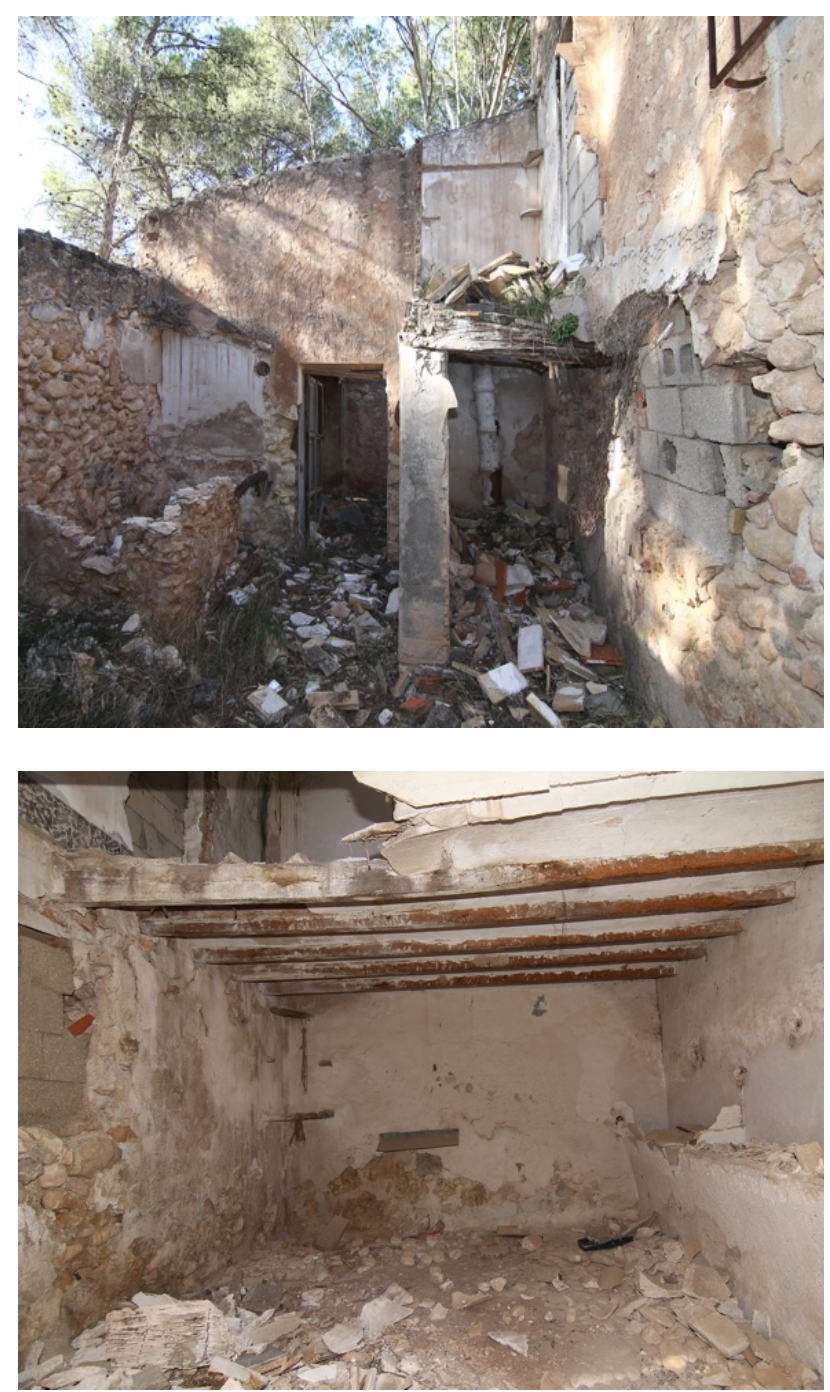

Figures 15 and 16. Courtyard and farmyards.

The first floor was intended for daily life -a blue and white living room with windows on the main façade toward the river (Figure 17), a simple kitchen (Figure 18) and a study- and the second floor included four bedrooms for the rest of the Torró family (Figure 19).

At a later date, possibly at the beginning of the twentieth century, an attached room with two floors was built in the original space of the courtyard. There was a living room with two lateral exits to the terraces on the first floor that could be accessed from the staircase, increasing its features as a pleasure house (Figure 20). 

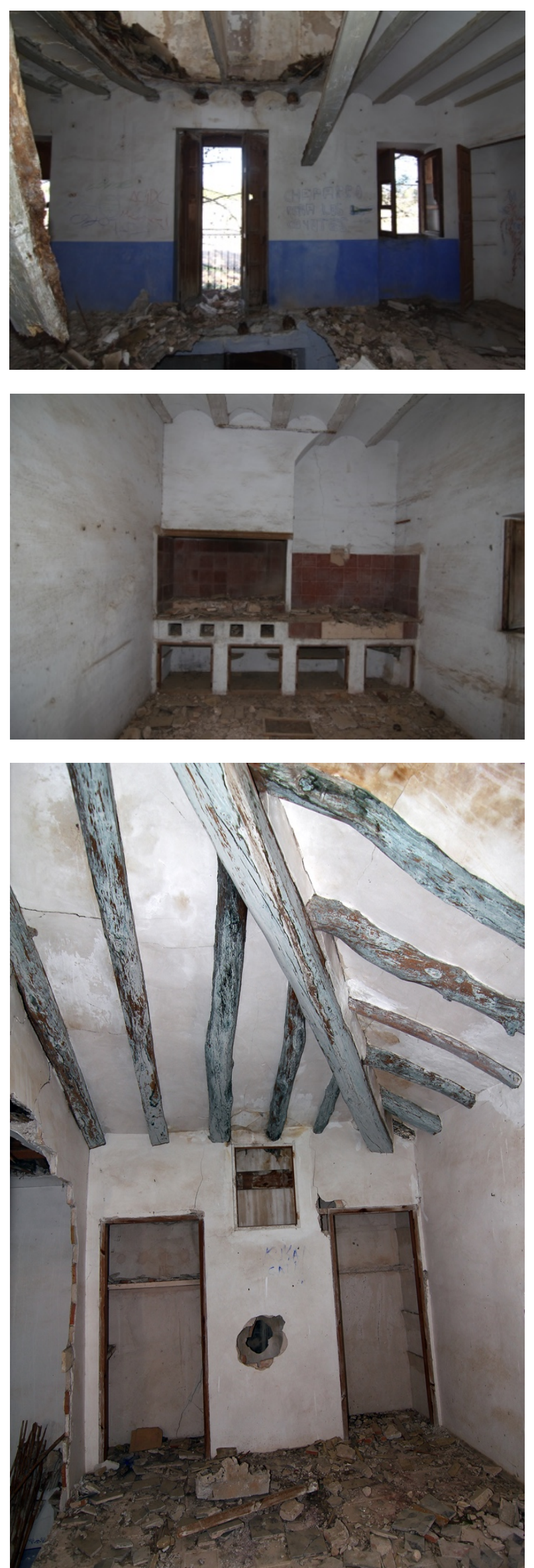

Figures 17, 18 and 19. Living room, kitchen, and bedrooms.

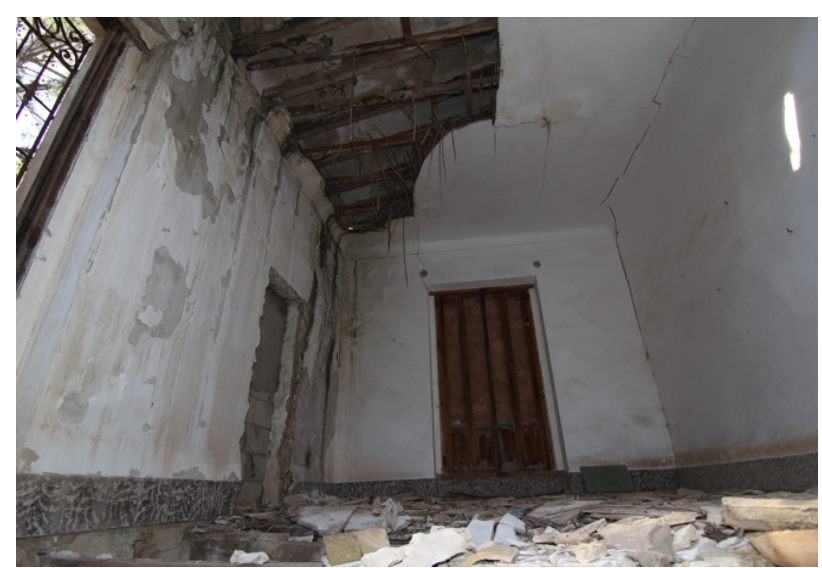

Figure 20. View of the new living room built in the twentieth century.

The house was conceived as a free-standing cube-shaped building, with main and lateral façades carefully designed (Figure 21). The first is made up by a basement that occupied the entire height of the ground floor, topped by a cornice with two pilasters (one at each corner) that incorporated Attic bases, striated shafts and Tuscan capitals. There was a simplified entablature highlighting the pronounced cornice on the top of the façade.

Its openings were organised: the main ones on a symmetry axis -access door and balcony- and those of minor importance on the second floor. Windows had lowered curved lintels bordered with flat stripes on the ground floor and mouldings on the rest of the floors. The balcony door was topped with a bouquet and acanthus waffle according to the classic style, as can be seen in Casa Américo of Alicante or the parochial church of Sant Joan d'Alacant.

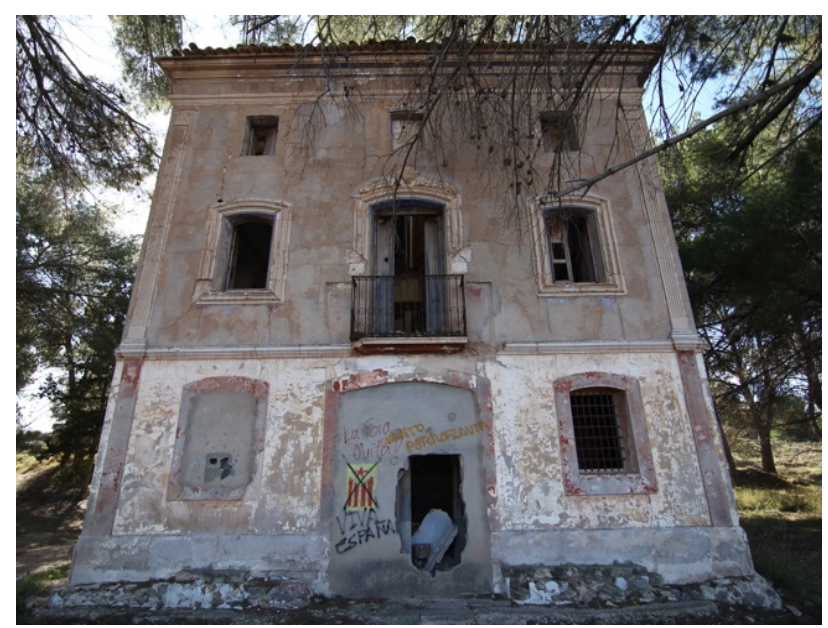

Figure 21. Current view of the main façade facing the river.

The two lateral façades repeated the composition of the main façade -basement, pilasters and entablature-, varying the number and dimensions of the moulded openings and with a moulded circle on the geometric centre filling the space left by the windows (Figure 22). All the architectural pieces (bases, pilasters, capitals, mouldings and cornices) were made with white plaster, using blood red colour for the ground floor, grey colour for the other two floors and blue colour for the cornice of the building. 


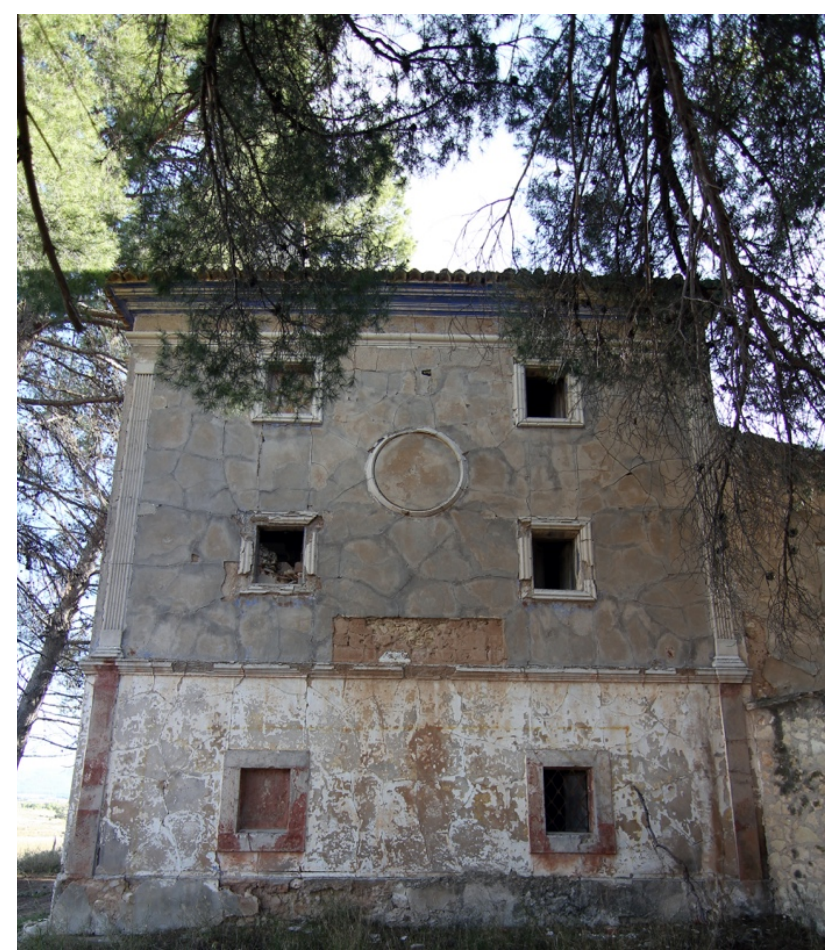

Figure 22. Composition of the west side façade.

The decline of the agricultural production in the country house motivated by the socio-economic changes in agriculture, its low profitability and the transformation of the Foia de Castalla district into an industrial and service society caused the gradual abandonment of the economic exploitation in many agricultural areas of Castalla during the twentieth century. In this sense, Castalla had only 10 doll factories in 1947 and the surplus of labour moved to the municipalities of Ibi and Onil in order to work in their factories (Cerdà, Espinosa, 2008, p. 193).

Consequently, the decline of the agricultural activity may have caused a loss of the economic capacity in Mas de la Parrotja (Figure 23) and the new Casa de la Glorieta. This fact led to their gradual abandonment that over time became the current state of ruin due to the intense plundering they have suffered, as can be noted in the images referring to Casa de la Glorieta. This situation was quite different in the mid-1980s of the twentieth century, as can be seen in the following images (Figures 24 and 25).

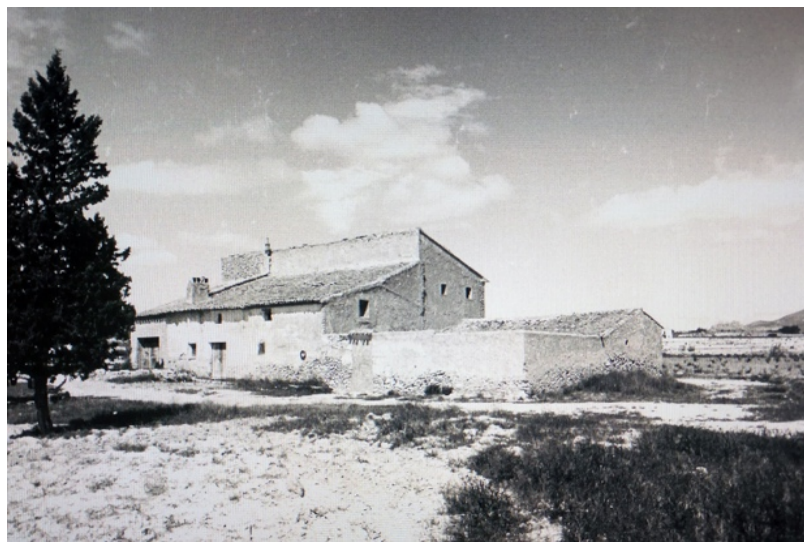

Figure 23. Mas de la Parrotja in 1984 when the building was standing.
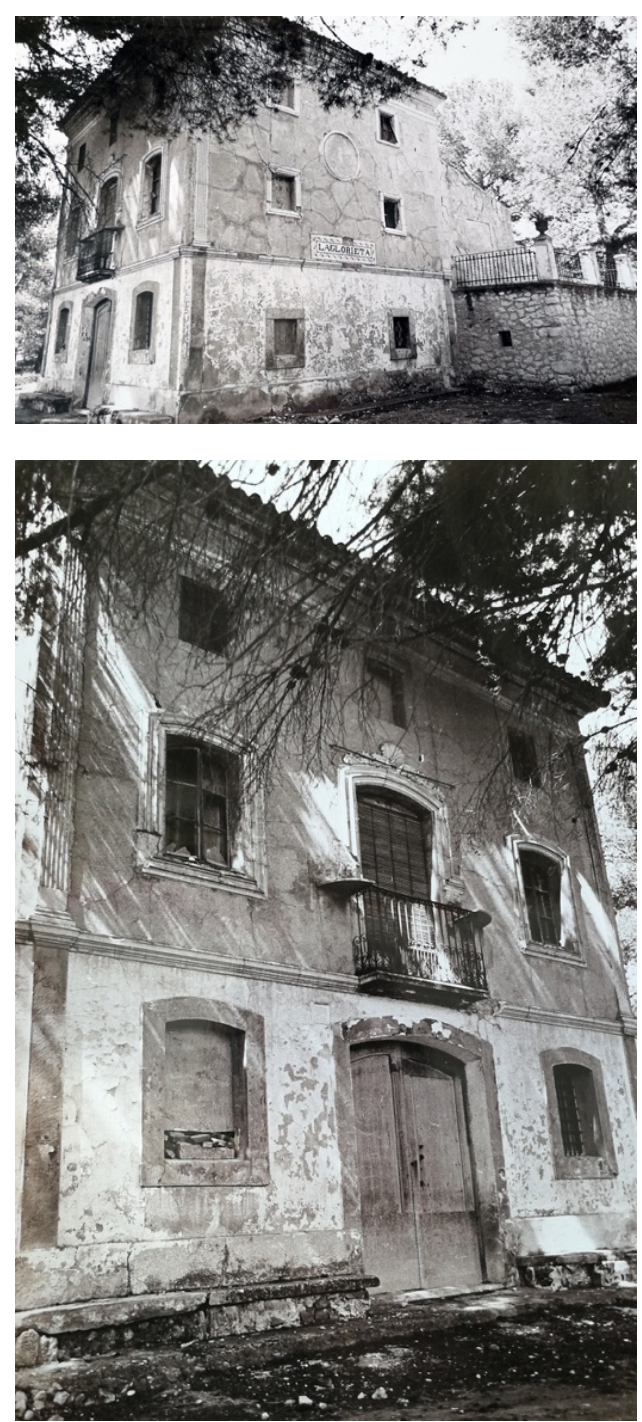

Figures 24 and 25. Casa de la Glorieta in 1984. It still preserved the original door, the wooden windows, the wooden blind of the balcony and the tiles with its name. (C) Joan Antoni

Bellot and Ildefonso Verdú Image Copyright 2020.

\section{CONCLUSIONS}

This work, which is a continuation of the photographic compilation task developed by Joan Antoni Bellot and Ildefonso Verdú in 1984, has become a new step for the detailed knowledge of vernacular architecture in the municipality of Castalla: country houses and pleasure houses traditionally encompassed under the category of country houses even though they are actually not. Although there is still much to do on this project, three typologies of pleasure constructions have been established: country houses, which can be complex (Figure 3) or simple (Figure 4), pleasure houses, and mixed ensembles made up by the first two types. Actually, an initial analysis has been carried out on a practical example-Casa de la Glorieta- which has yet to be developed much more. It is an interesting example of a mixed ensemble at local level since it is a pleasure house located next to a country house -Mas de la Parrotja- for the land use. It was built in the middle of the nineteenth century by the Torro family and its stylistic features are related to the models of that time. In addition, its ground floor configuration reminded other outstanding constructions in the province, such as the aforementioned Villa Ito or the town hall of Biar. 
The economic transformation of Castalla with the transition from an economy based on the primary sector to another based on the secondary sector, and the consequent loss of use of many country houses led to the abandonment of the ensemble made up by Mas de la Parrotja and Casa de la Glorieta: without the economic exploitation of the surrounding lands, these constructions became unsustainable properties for their owners. In this way, the loss of use derived in a progressive oblivion and in a lack of knowledge of its heritage importance increased by plundering and destruction due to the no-action of their owners and the administration in spite of being included in the Catalogue of Protected Assets of the General Land Use Planning of Castalla in 2001. In this sense, Casa de la Glorieta and Mas de la Parrotja have a degree 3 of (environmental) protection defined as "the constructions that, even without presenting a special value, contribute to define a valuable environment by its beauty, type or traditional character". Actually, it is not much because it allows "the demolition or remodelling of the façade and useful elements from the public road for a reconstruction and remodelling project or an alternative construction of higher architectural interest" (Laboratorio de Proyectos, 2001).

However, it is paradoxical that a society disconnected from the traditional way of life of previous generations and its tangible assets encourages their intangibility. The traditional dances of Castalla, for example, are a cultural manifestation that is part of the festivities related to the agricultural cycle of uncertain origin, at least for the moment, but perfectly documented at the end of the nineteenth century (1896) (Figure 26). On the other hand, the Moors and Christians festivity has a group called Maseros founded in 1929 in homage to the former inhabitants of the country houses, such as Mas de la Parrotja.

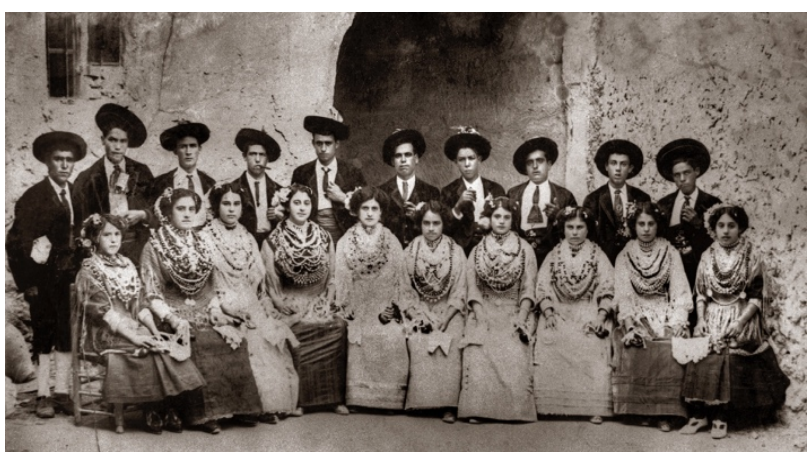

Figure 26. Kings and queens of the traditional dances in 1908. (C) Comissió de les Danses Image Copyright 2020.

This situation, together with the need to preserve their memory, has also promoted this research because these country houses and pleasure houses will become a residual and mythological element of the cultural landscape of Castalla and its inhabitants' memories in less than 50 years.

\section{REFERENCES}

Aróstegui, J., 2001: La investigación histórica: teoría y método. Crítica, Barcelona.

Balaguer, P. A., 2009: Las masías de la Sierra de Onil. Bubok Publishing, Spain.

Bérchez, J., Corell V., 1981: Catálogo de diseños de arquitectura de la Real Academia de Bellas Artes de San Carlos de Valencia (1768-1846). Colegio Oficial de Arquitectos de Valencia y Murcia, Valencia.
Bernabeu, J. L., 1984: Los límites simbólicos. Hombres de la Foia de Castalla y Vall de Xixona. Inst.de Estudios Alicatinos, Alicante.

Castalla, Cultura, Historia y Patrimonio, 2020. www.arepaccastalla.wordpress.com (5 January 2020).

Cerdà, F. J., Espinosa, J. Mª ., 2008: Castalla i el context històric: 1858-2008. In 150 aniversari. Comparsa dels Moros Grocs 18582008, 9-247. Comparsa dels Moros Grocs, Castalla.

Cruz, J., Segura, J. Mª, 1996: El comercio de la nieve: la red de pozos de nieve en las tierras valencianas. Generalitat Valenciana, València.

Flick, U., 2004: Introducción a la investigación cualitativa. Ediciones Morata, Madrid.

García, J., Rizo, C., 2003: Piedra, fuego y molienda: Las primeras industrias de yeso en la Foia de Castalla desde una perspectiva arqueológica. Actes del I Congrés d'Estudis de la Foia de Castalla Home i Paisatge, 59-73. Ajuntament de Castalla, Castalla.

Giménez, P., 2010: Medio físico y territorio en los dominios del Castell de Castalla: una introducción geográfica. In El Castell de Castalla. Arqueología, arquitectura e historia de una fortificación medieval de frontera, 269-274. MARQ, Alicante.

Laboratorio de Proyectos., 2001: Catálogo de Bienes y Espacios Protegidos del Plan General de Ordenación Urbana del término municipal de Castalla. Laboratorio de Proyectos, Alicante.

Madoz, P., 1847: Castalla. Diccionario geográfico-estadísticohistórico de España y sus posesiones de ultramar, tomo VI, 76 \& 77. La Ilustración, Madrid.

Marquiegui, Á., 2013: El patrimonio hidraúlico de la provincia de Alicante. Catálogo ilustrado de mil quinientes obras y actuaciones. Diputación de Alicante, Alicante.

Matarredona, E., Marco, J. A., 1991: El relieve y los suelos. In Atlas temático de la Comunidad Valenciana, I, 81-100. Prensa Alicantina, Alicante.

Mira, J. F., 1983: Temes d'etnografia valenciana, I. Poblament, arquitectura, condicions de la vida domèstica. Institució Alfons el Magnànim, València.

Mira, J. A., 2018: Castles landascapes in the southeast of the Iberian Peninsula: the example of Castalla Castle between the $11^{\text {th }}$ and $15^{\text {th }}$ centuries. Topiarius Landscape studies, 6, 11-23. doi.org/10.15584/topiarius.2018.6.2.

Ponce, G., Bonmatí, J. F., 1985: El hábitat rural. In Historia de la provincia de Alicante, $\mathrm{I}_{1}, 166-191$. Ed. Mediterráneo, Murcia.

Santos, Ma . J., 1987: La hoya de Castalla. Caja de Ahorros de Alicante y Murcia, Alcoy.

Taylor, S. J., Bogdan, R., 2002: Introducción a los métodos cualitativos de investigación. Paidós, Barcelona.

Turismo Castalla, 2020. www.turismocastalla.com (5 January 2020).

Valor, E., 1983: Temps de batuda. Tàndem Edicions, Alzira.

Varela, S., 1995: Arquitectura residencial en la huerta de Alicante. Instituto Alicantino de Cultura Juan Gil-Albert, Alicante.

Vasilachis, I., 2006: Estrategias de investigación cualitativa. GEDISA, Barcelona. 